\title{
Third-Party Signals in Crowdfunded [AQ1] Microfinance: The Role of Microfinance Institutions
}

Entrepreneurship Theory and Practice $00(0)|-2|$

(C) The Author(s) 2019

Article reuse guidelines: sagepub.com/journals-permissions DOI: I0.1 I 77//10422587/9839709 journals.sagepub.com/home/etp

\author{
Aaron H. Anglin' (D), Jeremy C. Short ${ }^{2}$, David J. Ketchen ${ }^{3}$, \\ Thomas H. Allison ${ }^{4}$ (iD, and Aaron F. McKenny
}

\begin{abstract}
Crowdfunded microfinance research has routinely examined how campaign characteristics drive funding to crowdfunding campaigns but has neglected to examine the critical role of the microfinance institution (MFI). We leverage signaling theory to contend that entrepreneurs' MFI affiliation is a salient third-party signal that shapes the performance of their crowdfunding campaign and examine how the financial and social performance of MFIs drive campaign funding. [AQ2]Our examination of 220,649 loans paired I73 MFIs supports our arguments. We provide insight into the importance of third-party signals in crowdfunding and into how investors seek to balance social motives with financial concerns in crowdfunded microfinance.
\end{abstract}

\section{Keywords}

microfinance, crowdfunding, signaling theory

[AQ3][AQ4]Microfinance holds vast potential as a weapon against poverty by providing impoverished individuals with modest unsecured loans enabling them to fund small ventures, thereby increasing their standard of living (Bruton, Khavul, \& Chavez, 2011; Canales \& Greenberg, 2016). However, the microfinance institutions (MFIs) that make and service these loans have historically struggled to find sufficient capital to fund their operations. MFIs are organizations that provide banking services to microenterprises in emerging markets and commonly operate with a social mission (Randøy, Strøm, \& Mersland, 2015). The emergence of crowdfunded microfinance - the pairing of localized MFIs in impoverished communities with nonprofit crowdfunding organizations - provides a potential solution to the capital constraints faced by

\footnotetext{
'Department of Entrepreneurship and Innovation, Texas Christian University, Fort Worth, TX, USA

${ }^{2}$ Division of Management \& International Business, Price College of Business, Norman, OK, USA

${ }^{3}$ Department of Management, Harbert College of Business, Auburn University, Auburn, AL, USA

${ }^{4}$ Department of Management, Information Systems, \& Entrepreneurship, Carson College of Business. Washington State University, Pullman, WA, USA

${ }^{5}$ Department of Management, College of Business Administration, University of Central Florida, Orlando, FL, USA
}

\section{Corresponding Author:}

Aaron H. Anglin, Department of Entrepreneurship and Innovation, Neeley School of Business, Texas Christian University, 2900 Lubbock Avenue, Fort Worth, TX, USA.

Email: a.anglin@tcu.edu 
MFIs (Moss, Neubaum, \& Meyskens, 2015). Crowdfunded microfinance enables MFIs to share the risk of a microloan among a set of individuals in wealthy countries who provide funding for the loans made by MFIs in poorer countries. For example, USA Today described how a Peruvian taxi driver was able to sustain rather than lose his business by borrowing $\$ 725$ to repair his vehicle from 29 people, each of whom provided an average of $\$ 25$ on Kiva.com - the world's largest crowdfunded microfinance organization (Marotta \& Russell, 2016).

As crowdfunded microfinance has blossomed into a billion dollar industry, research on crowdfunded microfinance has focused primarily on how campaign-related characteristics, such as the use of singular messaging or the gender of the entrepreneur, influence the funding of individual crowdfunding campaigns (e.g., Allison, Davis, Short, \& Webb, 2015; Galak, Small, \& Stephen, 2011; Moss, Renko, Block, \& Meyskens, 2018). While valuable in furthering knowledge concerning this important mechanism for financing poor entrepreneurs, research has largely neglected the role of the MFI in the crowdfunded microfinance ecosystem. MFIs are vital members of this ecosystem - they make and manage the initial loans, vet the entrepreneurs, and service crowdfunding websites with a supply of crowdfunding campaigns. Crowdfunding investor contributions made through the crowdfunding website act as a form of "insurance" for loans already made by the MFIs and allow MFIs to lend more freely to the poor. However, if MFIs mismanage loans, the crowdfunding investors may not be repaid-reducing their willingness to provide funds in the future and limiting a valuable supply of capital to poor entrepreneurs (Galak et al., 2011). Scholars have recognized the importance of the MFI and have called for research examining the role of the MFI (e.g., Moss et al., 2015), but these calls currently remain unanswered.

To begin addressing this gap, we draw from signaling research, particularly research examining third-party signaling, to address the question: How do entrepreneurs ' MFI affiliations affect the performance of their crowdfunding campaigns? Signaling theory contends that signalsdeliberate communications of organizational attributes - are used to infer the quality of the signaler and make decisions when the receiver lacks insider information about the signaler (Connelly, Certo, Ireland, \& Reutzel, 2011). Third-party signaling research examines how affiliations with other parties (e.g., strategic alliances, prominent investors, certification boards) act as signals to communicate the quality of the signaler (e.g., Gulati \& Higgins, 2003; Sadeh \& Kacker, 2018). Affiliations are key signals in that it is less costly for high-quality actors to establish thirdparty relations than it is for low-quality actors ([AQ5]Plummer, Allison \& Connelly, 2016; Spence, 1974). For example, an association with a prominent venture capital firm, given its track record of making profitable investments, serves as a positive signal for an entrepreneur intending to take his or her company public by suggesting that the company is a good investment (e.g., Elitzur \& Gavious, 2003). Because entrepreneurs choose to associate with MFIs in an effort to obtain financing, the MFI affiliation may serve as a salient signal to crowdfunding investors about the entrepreneur. Therefore, the characteristics of an MFI should provide insight into whether associated campaigns are worth funding. As such, we investigate how financial and social characteristics of 173 MFIs influenced fundraising for 220,649 crowdfunding campaigns.

We offer at least two potential contributions. First, we introduce MFI affiliation as a salient signal in crowdfunded microfinance by illustrating how the financial and social characteristics of MFIs drive funds to crowdfunding campaigns. A critical line of signaling research is devoted to teasing out and testing the influence of specific signals and determining under what conditions they are influential (e.g., Ozmel, Reuer, \& Gulati, 2013; Reuer, Tong, \& Wu, 2012). Following this lead, crowdfunded microfinance research has focused on identifying and testing signals originating within campaign content. We extend this line of inquiry by being the first to show the importance of third-party affiliations in raising crowdfunded microfinance. In doing so, we 
answer calls for investigation into (a) the role of MFIs in crowdfunded microfinance (e.g., Moss et al., 2015) and (b) how crowdfunding platforms can be used to communicate positive signals to prospective investors (e.g., Drover et al., 2017).

Second, we extend prior work suggesting that crowdfunded microfinance investors seek to balance their social motives with financial concerns, but have found social motivations exert a greater influence on funding performance than economic motivations. Allison et al. (2015) found that crowdfunding campaigns cast as an opportunity to help others or as a business opportunity both receive positive responses from investors; however, those cast as an opportunity to help others are received more positively. We extend this logic to MFI affiliations and show that both social and financial MFI characteristics shape funding performance, but that social characteristics have a greater impact on funding. Our work also broadly extends Allison et al. (2015) by advancing a signaling model of the social versus financial influences on funding. Finally, our work responds to concerns expressed in a recent Entrepreneurship Theory and Practice special issue that "scholarly knowledge about crowdfunding remains quite limited" despite its large and rapidly increasing "contribution to entrepreneurial fundraising" (Short, Ketchen, McKenny, Allison, \& Ireland, 2017).

\section{Background and Hypotheses}

\section{A Review of Crowdfunded Microfinance Research}

While the business models for crowdfunded microfinance platforms vary from platform to platform, many models consist of an ecosystem comprising MFIs, entrepreneurs, and crowdfunding investors brought together via a crowdfunding website such as Kiva or Babyloan. The MFIs are located in poor communities around the world and are responsible for making and servicing loans to entrepreneurs. After a loan is made, the MFI uploads information about the loan (e.g., amount, repayment terms, location), the entrepreneur (e.g., personal information, why the loan is needed, their home country), and the lending MFI (Moss et al., 2015). Crowdfunding platforms organize and post this information as crowdfunding campaigns. Investors, often located in wealthy countries, can then browse these campaigns and choose to support a portion of the loan. If the loan is fully funded on the crowdfunding website, the funds are transferred to the MFI who can then use the funds to lend to other entrepreneurs. As entrepreneurs repay the loans to the MFI, the crowdfunding investors are reimbursed for their individual contributions. Figure 1 provides a diagram of this process.

The rapid growth of crowdfunded microfinance as a mechanism to fund impoverished entrepreneurs has led to a burgeoning research stream. The majority of this research has focused on how entrepreneurs' characteristics and the contents of their campaigns facilitate fundraising through crowdfunding platforms. For instance, this research has revealed a preference for female borrowers (Galak et al., 2011). Similarly, campaigns expressing an entrepreneurial orientation (Moss et al., 2015), framing the business as an opportunity to help others (Allison et al., 2015), using charismatic rhetoric (Anglin, Allison, McKenny, \& Busenitz, 2014), and leveraging singular messaging (Moss et al., 2018) all improve funding outcomes. In addition, research examining the economic impact of crowdfunded microfinance indicates that this funding process may serve as an attractive mechanism to decrease financial exclusion of poor individuals (e.g., Marakkath \& Attuel-Mendès, 2015).

A notable omission in this research stream is the examination of the role of the MFI. Without MFIs, billions in individual loans to poor entrepreneurs would never be made (Thorpe, 2018). Because many of the entrepreneurs do not have the resources or expertise to create campaigns themselves, without MFIs, the supply of crowdfunding campaigns to the crowdfunding 


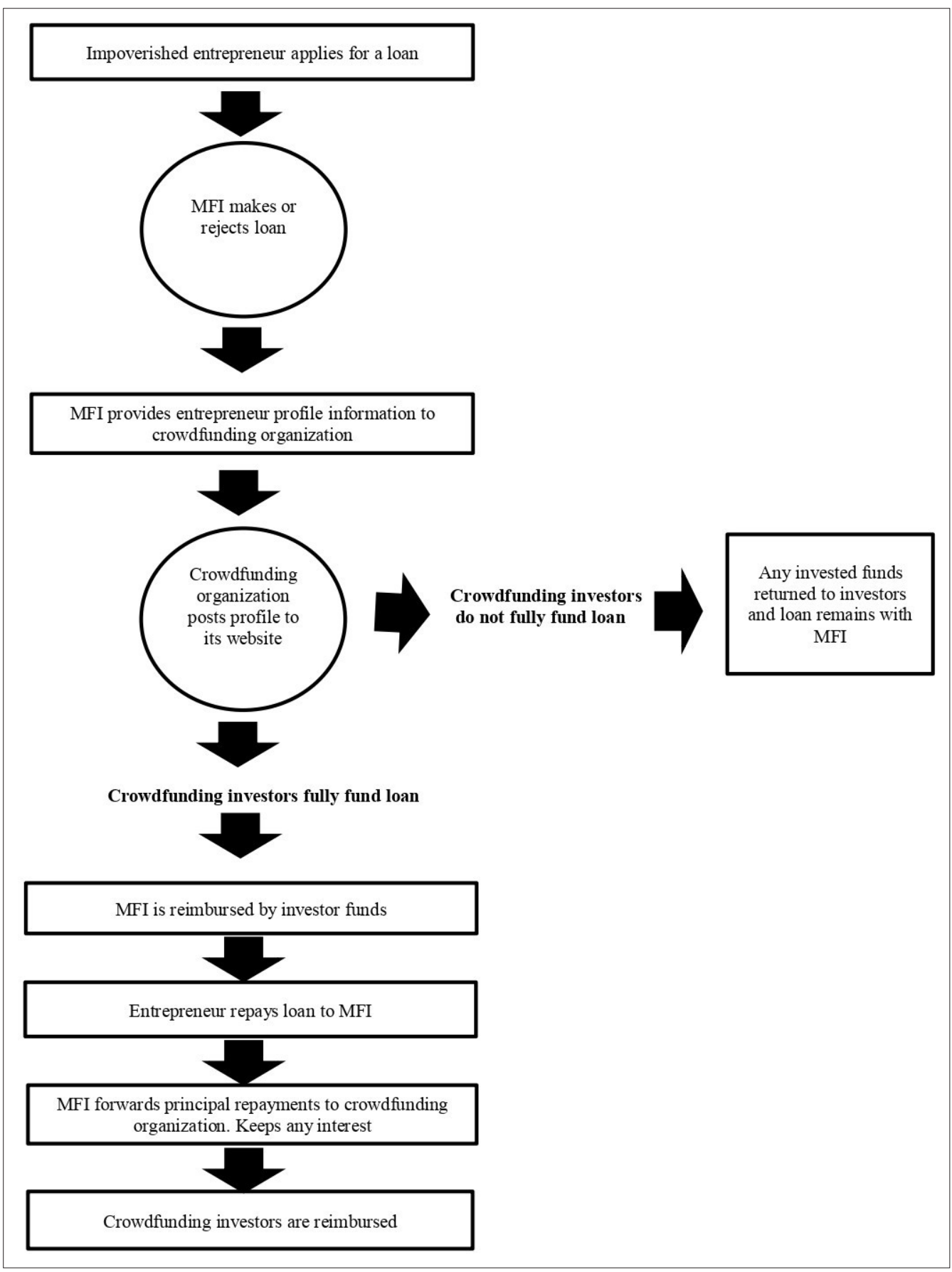

Figure I. Crowdfunded microfinance loan process (adapted from Allison, McKenny, \& Short, 20I3).

platforms would be drastically reduced. Further, it is incumbent on the MFI to ensure that loans are repaid, ensuring that the crowdfunding investors are subsequently repaid. As such, poor MFI performance could decrease the likelihood that individual investors will be repaid and reduce the 
willingness of investors to provide additional funds (Galak et al., 2011). A loss of crowdfunding contributions, then, decreases the supply of financial capital to MFIs that can be used to lend to other entrepreneurs. Likewise, crowdfunded microfinance is an inherently social cause (e.g., Anglin et al., 2014; Moss et al., 2018). MFIs viewed as not helping or taking advantage of the poor work against the overall mission of crowdfunded microfinance. Maintaining this social mission is critical to attracting funds because investors want to feel like they are participating in a good cause (e.g., Allison et al., 2013).

In sum, because MFIs play a critical in role in the crowdfunded microfinance ecosystem, researchers need to examine this important facilitator of the microfinance process to develop a better understanding of this ecosystem. Crowdfunding investors have access to information concerning the MFIs facilitating the loans they fund. It is likely, then, that characteristics of MFIs influence funding to crowdfunding campaigns. We turn to research on third-party signaling for insight into how the MFI may shape funding for individual crowdfunding campaigns.

\section{Third-Party Signals in Crowdfunding Microfinance}

Third-party signals are signals that arise from a signaler's affiliation with other parties (Elitzur \& Gavious, 2003; Dineen \& Allen, 2016). Third-party signaling research examines how these affiliations act as a signal to communicate quality concerning the signaler (e.g., Gulati \& Higgins, 2003; Sadeh \& Kacker, 2018). An affiliation with a third party is an important signal because the third party possesses characteristics that can be used to make inferences about the signaler (e.g., Dineen \& Allen, 2016; Gulati \& Higgins, 2003; Sadeh \& Kacker, 2018). For example, when an investment bank has a track record of backing successful IPOs, an entrepreneur whose IPO is underwritten by this bank signals that his or her firm is a good investment. Here the investment bank's track record positively shapes investors' perceptions about the likelihood that the IPO will be successful. Likewise, an affiliation with venture development organizations (e.g., Techstars, JumpStart, Y-Combinator) is a valuable signal for early-stage startups because these organizations are believed to be highly selective in their application process; consequently, only high quality firms are admitted to the programs ([AQ6]Plummer et al., 2016). For science-based organizations, an affiliation with a prestigious university, as measured through the number of bibliographic citations, is a positive signal during an IPO (Colombo, Meoli, \& Vismara, 2019). In addition, third parties are often believed to possess insider information that the receiver does not have (Bergh, Connelly, Ketchen, \& Shannon, 2014). If the third party is willing to associate with an entrepreneur, it is likely that the "inside information" is positive. Therefore, the affiliation is a positive indicator of the firm's quality.

Entrepreneurs who use crowdfunded microfinance often affiliate with MFIs in an attempt to improve their chances of obtaining financing. Therefore, an MFI affiliation may serve as a salient signal to crowdfunding investors concerning individual entrepreneurs. While the track records of individual entrepreneurs are unknown, investors can observe the history of the affiliated MFI. For instance, MFI default rates, profitability, and social performance metrics are monitored and reported on crowdfunding websites. Crowdfunded microfinance investors can use this information to draw inferences about entrepreneurs and their crowdfunding campaigns. For example, a low default rate would indicate that an MFI tends to make viable loans; therefore, entrepreneurs associated with this MFI are likely to repay their obligations. Further, because MFIs vet entrepreneurs in the initial loan process, an MFI should possess insider information concerning an entrepreneur. If a well-performing MFI is willing to lend to an entrepreneur, this likely suggests that the "insider information" is positive. In sum, the characteristics of an MFI should provide insight on whether a campaign is worth funding, thereby making MFI affiliation a potentially 
valuable signal for entrepreneurs. To probe this line of inquiry further, we investigate how the financial and social characteristics of MFIs facilitate fundraising in crowdfunding campaigns.

\section{MFI Financial Performance and the Likelihood of Funding}

Default rates are a key indicator of financial performance, because they provide a direct indication of the likelihood that loans will be repaid (Ahlin, Lin, \& Maio, 2011; Field, Pande, Papp, \& Rigol, 2013). Likewise, MFIs with high default rates are unsustainable and limit the social outreach of the MFI (Bhatt \& Tang, 2001). The default rates of MFIs signal the creditworthiness of the affiliated entrepreneurs. An affiliation with an MFI that has a lower default rate is a costly signal, because only those entrepreneurs who are most likely to repay a loan are able to make this affiliation, while entrepreneurs less likely to repay may have to affiliate with MFIs exhibiting higher default rates. As crowdfunding investors decide whether to provide funds to a crowdfunding campaign, higher MFI default rates signal that the individual entrepreneurs associated with the MFI represent greater risks. Investors can use the track record of the MFI to infer the likelihood that the entrepreneur will repay the loan. Though crowdfunding investors desire to make a social impact, research suggests that they are sensitive to the risks of lending to the poor (Allison et al., 2015). Accordingly, as the risk of lending increases, their willingness to fund the campaign should decrease with increasing default rates.

While the relationship between default rates and the likelihood of funding should be negative, this relationship is likely nonlinear. Although risk preferences likely vary among crowdfunding investors, as default rates rise, investors should become less willing to lend. Indeed, despite making relatively small investments, crowdfunding investors tend to be risk averse (e.g., Chan \& Parhankangas, 2017; Paravisini, Rappoport, \& Ravina, 2017). Likewise, research examining risk preferences among individuals indicates that the distribution of risk preferences is not normal, with a greater concentration of individuals exhibiting "lower" risk preferences and a decreasing number of individuals willing to assume risk as the chance of loss increases (e.g., Chavas \& Holt, 1996). Those with the lowest risk preferences will stop lending first, which should make up a greater volume of potential lenders, leaving a smaller population of potential lenders as default rates rise. Because fewer individuals are available to lend, the overall impact of lenders continuing to drop out will diminish. Eventually, lending will simply stop at higher levels. Thus, we expect the overall negative relationship between default rates and the likelihood of funding to exhibit a nonlinear relationship where the impact of default rates levels off as default rates rise. Stated formally,

Hypothesis 1: Higher MFI default rates will be negatively associated with the likelihood of a crowdfunding campaign being funded. This relationship will be nonlinear, accelerating as default rates rise, but leveling off at higher default rates.

Another salient indicator of financial performance is profitability. MFIs that are more profitable are viewed as better managed, more selective of their clientele, and capable of making good lending decisions (e.g., Daher \& Le Saout, 2013; Kyereboah-Coleman \& Osei, 2008). An entrepreneur's association with more profitable MFIs may signal that the entrepreneur is a less-risky investment. Indeed, management and finance research long has shown that superior profitability increases a third party's credibility (e.g., Chemmanur \& Fulghieri, 1994) and illustrated links between profitability and reputation (e.g., Roberts \& Dowling, 2002). Accordingly, associations with these third parties may act as a key signal within the venture financing process (Drover et al., 2017). An association with a more profitable MFI is a costly signal because it can only be realized by entrepreneurs who meet the selective criteria of the MFI. However, because 
crowdfunded microfinance investors are socially inclined (Galak et al., 2011), high levels of profitability could indicate an overemphasis on financial concerns at the expense of social concerns. Seeking greater profitability often reduces the financial inclusiveness of MFIs and results in a shift away from helping the poor (Aduda \& Kalunda, 2012). Thus, although profitability indicates less risk, at higher levels, the perceived lack of emphasis on helping the poor should negatively impact the willingness to fund crowdfunding campaigns. Accordingly, we expect MFI profitability to exhibit an inverted-U relationship with the likelihood of a crowdfunding campaign being funded. Stated formally,

Hypothesis 2: An MFI's profitability has an inverted-U relationship with the likelihood of a crowdfunding campaign being funded.

\section{MFI Social Performance and the Likelihood of Funding}

A key indication of social performance in crowdfunded microfinance is an MFI's average loan size as a percentage of per capita income of the country in which the loan is made (Mersland \& Urgeghe, 2013). When loan size is held constant, this metric increases as larger loans are made in poorer countries. As such, it is widely seen as indicative of an MFI's willingness to help poorer entrepreneurs because the MFIs are willing to incur the risk of helping individuals who are the least able to repay the loan (e.g., D'Espallier, Hudon, \& Szafarz, 2013; Randøy et al., 2015).

Crowdfunded microfinance investors lend, in part, because they want to aid poor individuals and derive good feelings from doing so (Allison et al., 2013, 2015). Because an MFI's average loan size as a percentage of per capita income is an indication of an MFI's willingness to aid the poor (Randøy et al., 2015), loans made by MFIs higher in this metric are likely viewed as made to truly poor individuals. Entrepreneurs associated with MFIs higher in this metric signal that they are the most in need of funds. In addition, the willingness of impoverished entrepreneurs to incur the risk of the loan, despite their circumstances, is a costly endeavor and may signal a strong commitment to their business (e.g., Becchetti \& Conzo, 2011). Funding these individuals provides investors with an opportunity to fulfill the desire to enable poor entrepreneurs to launch or grow a business. Accordingly, we expect that as the loan size as a percentage of per capita income increases that there is an increase in the likelihood of funding for individual loans associated with these MFIs.

Although crowdfunded microfinance investors are concerned with the social impact of their investments, they are also conscious of the risk of lending to the poor and expect to be repaid (Moss et al., 2015). Indeed, crowdfunded microfinance research indicates that investors seek to balance their desire to help others with the risks associated with lending to the poor (Allison et al., 2015). As larger loans are made to poorer individuals, the risk that these loans may not be paid back increases ([AQ7]Mersland \& Strøm, 2009). If the loans are not paid back, investors are not reimbursed for their contributions to the loan. It is unlikely, then, that increasing the average loan size as a percent of per capita income is viewed as favorable at all levels. In fact, because higher loan/income ratios are associated with higher repayment risk, at higher levels further increases may dissuade investors' willingness to lend. Thus, at higher levels of MFI average loan size as a percent of per capita income, the affiliation with an MFI is no longer viewed as a positive signal and the likelihood that a campaign will be funded will decrease. In sum, we expect that this metric has an inverted-U relationship with the likelihood of a loan being funded.

Stated formally, 
Hypothesis 3: An MFI's average loan size as a percentage of per capita income will have an inverted-U relationship with the likelihood of a crowdfunding campaign being funded.

Another indicator of social performance is the cost to borrowers (e.g., Roberts, 2013; Sun \& Im, 2015). MFIs with a stronger emphasis on helping the poor seek to reduce borrowing costs. For instance, research has found that MFIs with lower interest rates may have a stronger shared vision of poverty alleviation among loan officers and employees of an MFI (Sun \& Im, 2015). Further, MFIs charging higher interests are often viewed as exploiting the poor, because these individuals have limited alternative sources of funding ([AQ8]Rosenberg, Gonzalez, \& Narain, 2009). An entrepreneur affiliated with an MFI with lower borrowing costs signals that investing in the entrepreneur provides an opportunity to help a poor individual in a fair, socially impactful manner. In addition, while less-costly to the entrepreneur in monetary terms, obtaining loans at a lower borrowing cost can be considered costly from a signaling perspective because such loans suggest that entrepreneurs are more credit worthy. Indeed, microfinance research has found that demonstrated creditworthiness operates as positive signals to other parties (e.g., Becchetti \& Conzo, 2011). As the cost to borrowers rises, however, crowdfunded microfinance investors should be less likely to fund campaigns because this reduces the social impact of their investment.

This relationship should be nonlinear. Although lower borrowing costs are preferred, it is likely that crowdfunding investors expect there to be costs associated with originating and servicing the loan. Kiva, for example, states "...most Kiva borrowers do pay interest to our Field Partners in some form" (Kiva, 2018a). It is reasonable to expect that some investors continue to lend to entrepreneurs with higher borrowing cost loans. However, the number of investors willing to contribute should shrink as borrowing costs rise in light of the reduced social impact. Because fewer individuals are available to contribute, the overall impact of investors continuing to drop out on the willingness to fund a campaign will diminish. Eventually, contribution rates will stay the same beyond a higher borrowing cost threshold. Thus, we expect the overall negative relationship between borrowing costs and the likelihood of funding to exhibit a nonlinear relationship where the impact of borrowing costs levels off as borrowing costs rise. Stated formally,

Hypothesis 4: Higher average loan cost to the entrepreneur will be negatively associated with the likelihood of a crowdfunding campaign being funded. This relationship will be nonlinear, accelerating as borrowing costs rise, but leveling off at higher levels of borrowing costs.

\section{Method}

Our sample is collected from Kiva, the world's largest crowdfunded microfinance platform, which has facilitated over 1.1 billion USD in loans (Kiva, 2018a) and partners with MFIs around the globe that make and administer loans to the poor (Kiva, 2018b). Throughout 2016, Kiva underwent a redesign of their platform to improve the user experience leading to its current design. This design features information concerning the MFI administering each loan on the right-hand side of the individual crowdfunding campaign page and includes financial and social performance metrics. Accordingly, crowdfunding investors can easily assess the performance of the MFI. Because of the redesign of the platform in 2016, we collected data from Kivatools.com on individual loans posted from January 1, 2017 through February 28, 2018 (when the dataset ended at the time of collection) and paired these loans with the corresponding data on the MFI administering the loan. We began with 224,671 loans. The loan data includes direct loans (i.e., 
loans made without an MFI) because Kiva began allowing direct loans in recent years as a growth strategy. However, these loans are largely made to U.S.-based small businesses and most loans posted Kiva are not direct loans. Accordingly, 2,244 direct loans are excluded from our analysis. This left us with 222,427 loans. We further excluded loans made by Kiva partners operating under "experimental" status. This status is used for partners to test their Kiva lending program before scaling their program. These partnerships often do not have complete information about MFI performance reported. We exclude an additional 1,778 loans made by these partners. In total, we were able to match 220,649 loans with 173 MFIs. This represents approximately $98 \%$ of all loans posted to Kiva over the time frame of the study.

\section{Dependent Variable}

The dependent variable, success, reflects whether or not the campaign met its funding target set at the beginning of the campaign (e.g., Allison et al., 2013; Anglin et al., 2018). This is one of the most commonly used dependent variables in crowdfunding research and in broader venture financing research (e.g., Ahlers, Cumming, Günther, \& Schweizer, 2015; Anglin et al., 2018; Josefy, Dean, Albert, \& Fitza, 2017). If the campaign met its target, the success variable was coded as " 1 ." If the campaign missed its target, the success variable was coded as " $0 . "$

\section{Independent Variables}

Our study addresses four independent variables: two financial performance variables and two social performance variables. All of these variables can be viewed on the right-hand side of the individual crowdfunding campaign web page. For financial performance, we assess MFI default rate and profitability. Default rate is calculated as the percentage of funded loans that were not repaid. To capture profitability, we use the MFIs' return on assets (e.g., Kyereboah-Coleman \& Osei, 2008), which is a commonly used measure of firm-level financial performance (Jeong \& Harrison, 2017) and the main profitability measure for MFIs reported by Kiva. To capture social performance, we use an MFI's average loan size as percentage of per capita income and average cost to borrower. The average loan size as percentage of per capita income is calculated by dividing the MFI's average loan size by its country's gross national income (per capita) and multiplying by 100. For example, if an MFI's average loan size is $\$ 100$ and per capita income is $\$ 1000$, this metric would equal $10 \%$. If a country's per capita income is $\$ 10,000$ this metric would equal $1 \%$. We use the MFI's portfolio yield, calculated as the MFI's financial earnings divided by its average loan portfolio outstanding during a given year, to approximate an MFI's average cost to borrower. The default rate and average loan size as percentage of per capita variables are right-skewed and include zero values. As such, we use the inverse [AQ9]hyperbolic sine (ihs) transformation to normalize these variables. This is akin to a natural log transformation, yet it can account for zero values, and is interpreted in the same way as a natural log (Sauerwald, Lin, \& Peng, 2016).

\section{Controls}

We introduce several controls to account for established antecedents predicting funding success. We include the natural log of loan size, natural log of loan term, the natural log of the word length of the loan descriptions, dummy variables to account for the repayment interval (i.e., monthly, bullet, or irregular), and a dummy variable coded as " 1 " if the loan was made to a group and " 0 " if made to an individual to control for loan characteristics shown to influence funding (e.g., Allison et al., 2013; Moss et al., 2018). We use a dummy variable coded as "1" for female if the 
crowdfunding campaign includes a female borrower because of the demonstrated preferences for funding females through crowdfunding (Moss et al., 2015). We control for the risk rating assigned to the MFI by Kiva resulting from Kiva's due diligence processes (Galak et al., 2011). Finally, we use dummy variables to account for the economic sector classification of each loan (e.g., Allison et al., 2015).

\section{Statistical Procedures}

We use multilevel logistic regression to estimate our results using the melogit command in Stata. Crowdfunding data are routinely nested, making multilevel designs beneficial for estimating models using crowdfunding data (Anglin et al., 2018). Nested observations violate the independence assumptions associated with traditional regression techniques, consequently multilevel approaches allow us to address this lack of independence (Aguinis \& Culpepper, 2015). Further, the logistic portion of our regression enables us to account for the fact that our dependent variable can only take values of " 0 " and " 1 ." In our dataset, each individual loan is paired with one of 173 MFIs. As such, each loan is nested within an MFI. While our controls and independent variables account for a portion of the variance attributed to funding success by the MFIs, there may be other aspects of MFIs that we cannot account for that influence success. By accounting for the nesting of individual loans within MFIs, we are able to account for this unobserved variance. Each loan (and MFI) is further nested within the country in which they are located, which may have unique characteristics (cultural, economic, etc.) that influence funding success. We must address this variance as well. Therefore, when we estimate our models, the individual loans make up level 1 (i.e., the fixed effects), the MFIs make up level 2, and home countries make up level 3.

\section{Results}

Table 1 provides the descriptive statistics for our sample and Table 2 provides the results for our hypothesis tests. We provide the log odds coefficients and marginal effects (ME), which lend themselves to a more "linear" interpretation (i.e., a change in $x$ is associated with change in $y$; Hoetker, 2007). Hypothesis 1 proposed that an MFI's default rate will have a negative relationship with the likelihood of a crowdfunding campaign being funded as default rates rise, but level off at higher default rates. Consistent with this relationship, the linear term is negative $(b=-1.77$, $p<.01 ; \mathrm{ME}=-0.05, p<.01)$ and the quadratic term is positive $(b=0.58, p<.01 ; \mathrm{ME}=0.02, p$ $<.01$ ) for default rates. Figure 1 indicates a convex relationship between MFI default rates and funding success consistent with Hypothesis 1. Thus, Hypothesis 1 is supported. Our results suggest that MFI default rates cease to influence the likelihood of funding (i.e., the relationship is flat) at approximately $4.6 \%$.

Hypothesis 2 proposed an inverted-U relationship between MFI profitability and funding success. The linear term is negative $(b=-0.02, p>.05 ; \mathrm{ME}=0.00, p>.05)$ and the quadratic term is positive $(b=0.00, p>.05 ; \mathrm{ME}=0.00, p>.05)$, but neither is significant. Thus, Hypothesis 2 is not supported.

Hypothesis 3 proposed an inverted- $U$ relationship between an average loan size as a percentage of per capita income and funding success. The linear term is positive $(b=0.67, p<.05$; ME $=0.02, p<.01)$ and the quadratic term is negative $(b=-0.16, p<.01 ; \mathrm{ME}=-0.004, p<.01)$. Figure 2 is consistent with an inverted-U relationship. Thus, Hypothesis 3 is supported. The inflection point occurs at approximately $12.2 \%$ for the average loan size as a percentage of per capita income. 


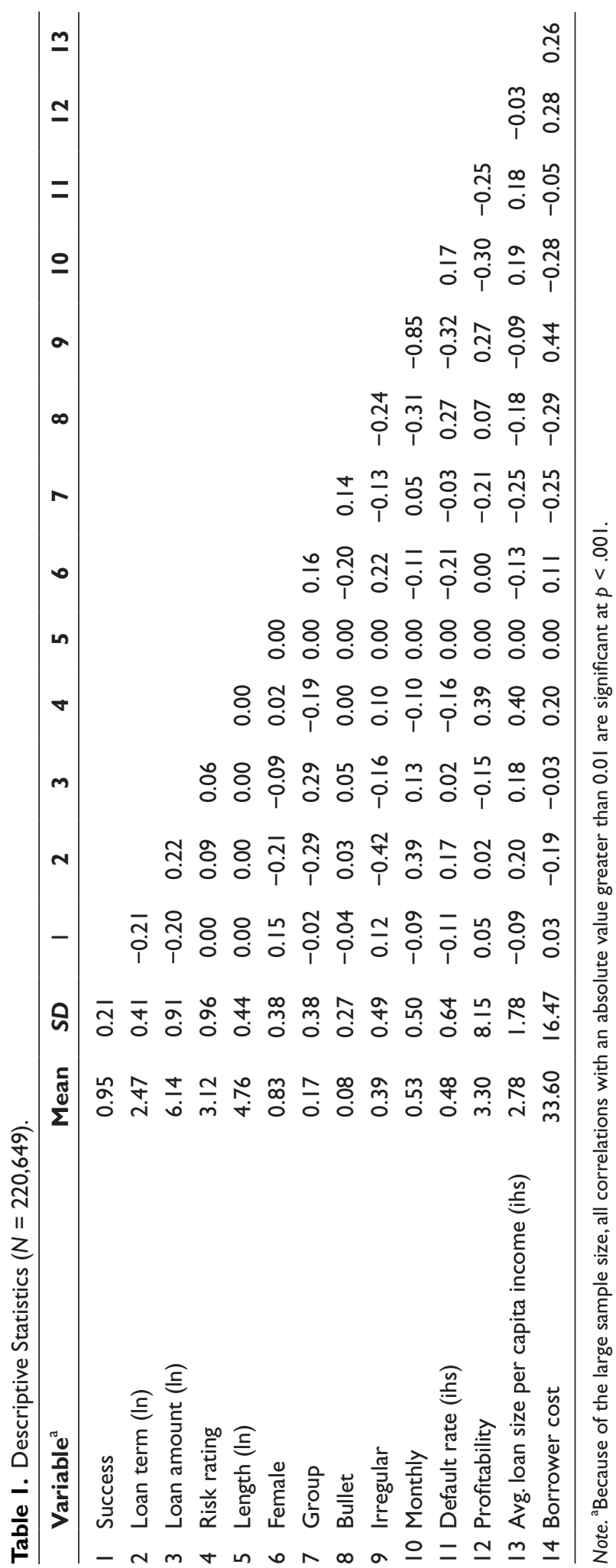


Table 2. Financial and Social Performance on the Likelihood of Funding.

\begin{tabular}{|c|c|c|c|c|}
\hline Variables $^{\mathrm{a}}$ & $\begin{array}{l}\text { Controls } \\
\text { (log odds) }\end{array}$ & $\begin{array}{c}\text { Controls } \\
\text { (ME) }\end{array}$ & $\begin{array}{l}\text { Main effects } \\
\text { (log odds) }\end{array}$ & $\begin{array}{c}\text { Main effects } \\
\text { (ME) }\end{array}$ \\
\hline Loan term (In) & $\begin{array}{c}-2.33^{* * * *} \\
(0.06)\end{array}$ & $\begin{array}{c}-0.06 * * * \\
(0.01)\end{array}$ & $\begin{array}{c}-2.34^{* * * *} \\
(0.06)\end{array}$ & $\begin{array}{c}-0.06^{* * * *} \\
(0.01)\end{array}$ \\
\hline Loan amount (In) & $\begin{array}{c}-1.87^{* * * *} \\
(0.03)\end{array}$ & $\begin{array}{c}-0.05^{* * * *} \\
(0.01)\end{array}$ & $\begin{array}{c}-1.86 * * * \\
(0.03)\end{array}$ & $\begin{array}{c}-0.05^{* * * *} \\
(0.01)\end{array}$ \\
\hline Risk rating & $\begin{array}{l}-0.40 \\
(0.17)\end{array}$ & $\begin{array}{l}-0.01 \\
(0.01)\end{array}$ & $\begin{array}{c}0.11 \\
(0.18)\end{array}$ & $\begin{array}{c}0.00 \\
(0.00)\end{array}$ \\
\hline Length (In) & $\begin{array}{l}-0.00 \\
(0.03)\end{array}$ & $\begin{array}{c}0.00 \\
(0.00)\end{array}$ & $\begin{array}{c}0.00 \\
(0.03)\end{array}$ & $\begin{array}{c}0.00 \\
(0.00)\end{array}$ \\
\hline Female & $\begin{array}{c}\text { I.56*** } \\
(0.00)\end{array}$ & $\begin{array}{c}0.04^{* * * *} \\
(0.00)\end{array}$ & $\begin{array}{c}\text { I.56*** } \\
(0.03)\end{array}$ & $\begin{array}{c}0.04 * * * \\
(0.00)\end{array}$ \\
\hline Group & $\begin{array}{c}0.12 \\
(0.08)\end{array}$ & $\begin{array}{c}0.00 \\
(0.00)\end{array}$ & $\begin{array}{c}0.11 \\
(0.08)\end{array}$ & $\begin{array}{c}0.00 \\
(0.00)\end{array}$ \\
\hline Irregular & $\begin{array}{c}0.05 \\
(0.09)\end{array}$ & $\begin{array}{c}0.00 \\
(0.00)\end{array}$ & $\begin{array}{c}0.07 \\
(0.09)\end{array}$ & $\begin{array}{c}0.00 \\
(0.00)\end{array}$ \\
\hline Monthly & $\begin{array}{c}0.12 \\
(0.09)\end{array}$ & $\begin{array}{c}0.01 \\
(0.00)\end{array}$ & $\begin{array}{c}0.12 \\
(0.09)\end{array}$ & $\begin{array}{c}0.01 \\
(0.00)\end{array}$ \\
\hline Fourteen sector dummies ${ }^{b}$ & Included & Included & Included & Included \\
\hline Default rate (ihs) & & & $\begin{array}{c}-1.77 * * \\
(0.56)\end{array}$ & $\begin{array}{c}-0.05^{* *} \\
(0.02)\end{array}$ \\
\hline [AQ10]Default rate ${ }^{2}$ (ihs) & & & $\begin{array}{l}0.58^{* * *} \\
(0.19)\end{array}$ & $\begin{array}{l}0.02 * * \\
(0.00)\end{array}$ \\
\hline Profitability & & & $\begin{array}{l}-0.02 \\
(0.01)\end{array}$ & $\begin{array}{c}0.00 \\
(0.00)\end{array}$ \\
\hline Profitability $^{2}$ & & & $\begin{array}{c}0.00 \\
(0.00)\end{array}$ & $\begin{array}{c}0.00 \\
(0.00)\end{array}$ \\
\hline Avg. loan size per capita income (ihs) & & & $\begin{array}{l}0.67 * \\
(0.31)\end{array}$ & $\begin{array}{l}0.02 * * \\
(0.00)\end{array}$ \\
\hline Avg. loan size per capita income ${ }^{2}$ (ihs) & & & $\begin{array}{c}-0.16 * * * \\
(0.04)\end{array}$ & $\begin{array}{c}-0.004^{* *} \\
(0.00)\end{array}$ \\
\hline Cost to borrower & & & $\begin{array}{c}-0.14 * * * \\
(0.03)\end{array}$ & $\begin{array}{c}-0.004 * * * * \\
(0.00)\end{array}$ \\
\hline Cost to borrower ${ }^{2}$ & & & $\begin{array}{c}0.002^{* * * *} \\
(0.00)\end{array}$ & $\begin{array}{c}0.000 I^{* * * *} \\
(0.00)\end{array}$ \\
\hline Constant & $\begin{array}{c}23.51 \text { **** } \\
(0.52)\end{array}$ & & $\begin{array}{c}24.69 \text { ***** } \\
(0.65)\end{array}$ & \\
\hline \multicolumn{5}{|l|}{ Variance components } \\
\hline MFI & $\begin{array}{c}0.00 \\
(0.00)\end{array}$ & & $\begin{array}{c}0.00 \\
(0.02)\end{array}$ & \\
\hline Country & $\begin{array}{c}5.87 \text { **** } \\
(0.82)\end{array}$ & & $\begin{array}{c}3.77 \text { **** } \\
(0.52)\end{array}$ & \\
\hline Log likelihood & $-25,610.84$ & & $-25,527.08$ & \\
\hline$\chi^{2}$ & $9,731.93$ & & $9,761.62$ & \\
\hline Number of loans & 220,649 & & 220,649 & \\
\hline Number of MFIs & 173 & & 173 & \\
\hline
\end{tabular}

${ }^{\mathrm{a}} \mathrm{S}$ tandard errors in parentheses. ${ }^{\mathrm{b}}$ Eleven II sectors significant at $p<.00 \mathrm{I}$ and I sector significant at $p<.05$. Note. ${ }^{*} p<.05 . * * p<.01 .{ }^{* * *} p<.001$. 


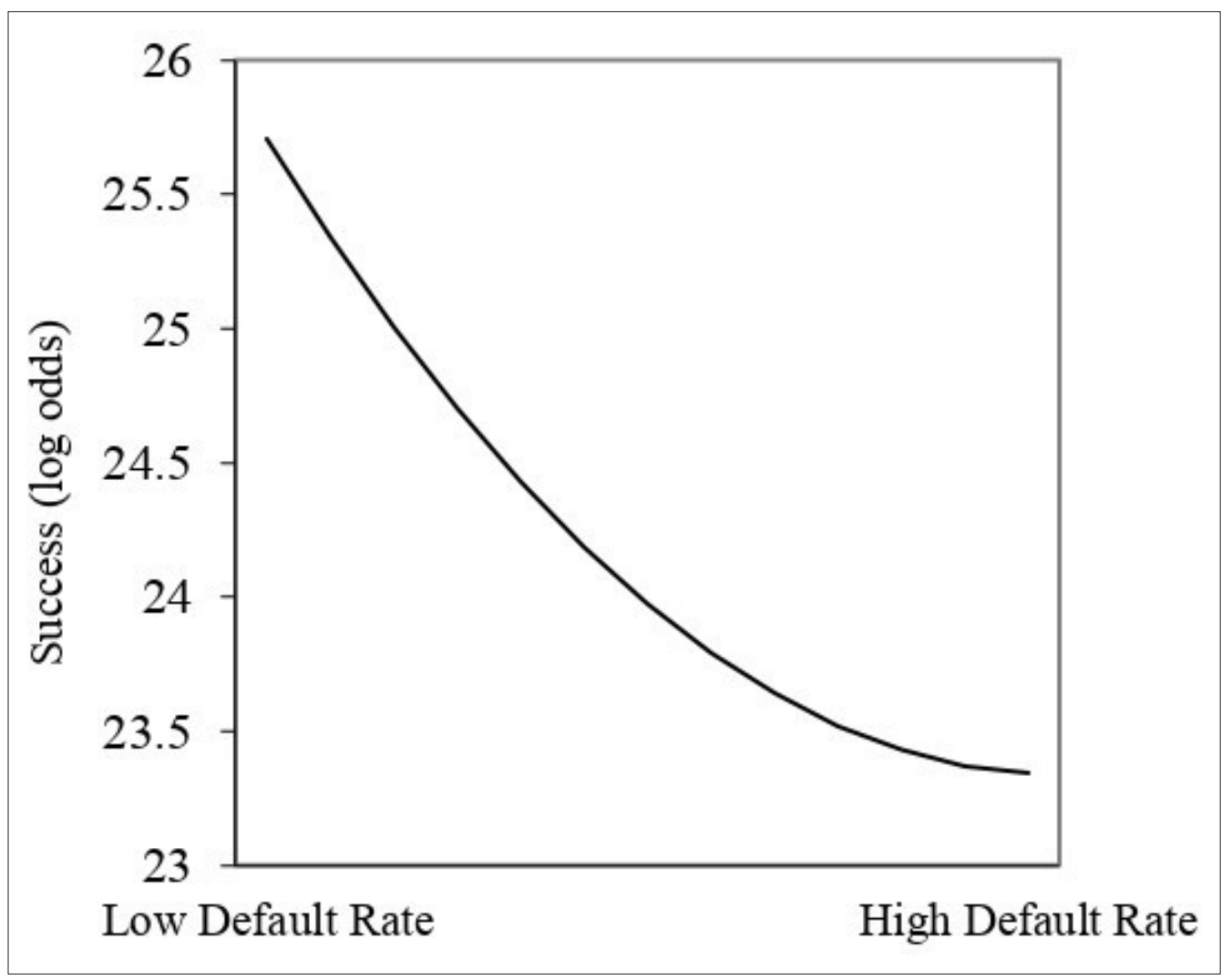

Figure 2. Default rates on success.

Hypothesis 4 proposed that a higher average cost to borrowers will be negatively associated with the likelihood of a crowdfunding campaign being funded, but will level off at higher levels of borrowing costs. The linear term is negative $(b=-0.14, p<.001 ; \mathrm{ME}=-0.004, p<.001)$ and the quadratic term is positive $(b=0.002, p<.001 ; \mathrm{ME}=0.0001, p<.001)$. Figure 3 is consistent with the notion of a negative relationship that levels off at higher borrowing costs. Thus, Hypothesis 4 is supported. The relationship flattens at an approximate cost to borrowers of $35 \%$.

\section{Post Hoc: Dominance Analysis}

While our results suggest that an entrepreneur's MFI affiliation serves as a salient signal in crowdfunded microfinance, they provide less insight into which concerns (financial vs. social) are most important to investors. Given that investors balance both financial and social concerns when evaluating whether to fund entrepreneurs (e.g., Allison et al., 2015; Moss et al., 2015), a natural extension of such findings is to examine how investors weight MFI financial versus social performance. Accordingly, we conduct a dominance analysis on our independent variables. Dominance analysis is a means of determining the relative importance of independent variables through a pairwise comparison of all predictors (Budescu, 1993). The relative importance of a variable based on the variable's "reduction of error" in predicting the dependent variable, which is used to produce dominance statistics for each variable that enables researchers to rank the importance of variables (Johnson \& Lebreton, 2004). Because we examine quadratic effects, 


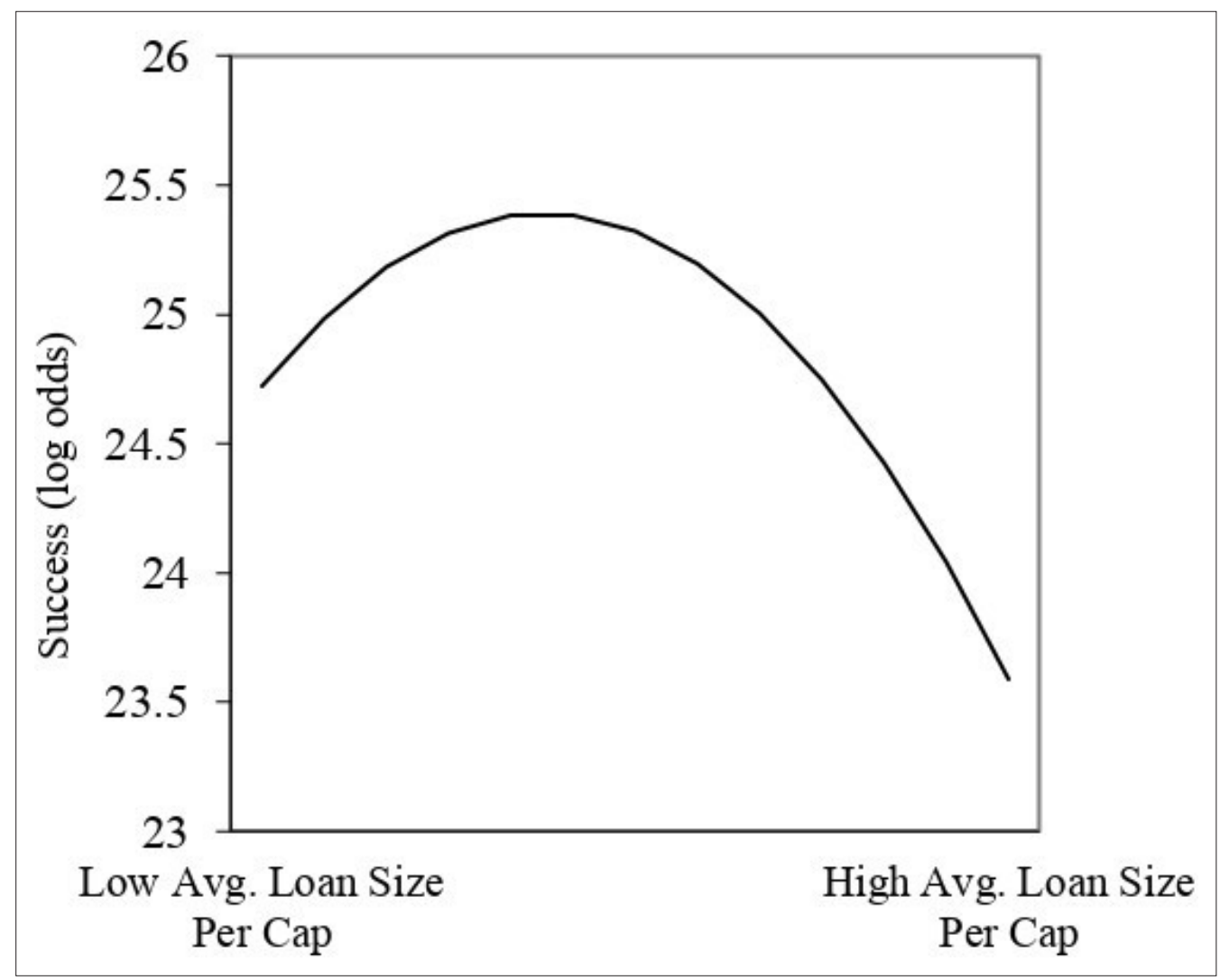

Figure 3. Average loan size as a percent of per capita income on success.

each variable is ranked on the combined standardized dominance score of the linear and quadratic term. The combined standardized dominance scores were as follows: default rates $=0.30$, profitability $=0.02$, average loan size as a percentage of per capita income $=0.42$, and cost to entrepreneur $=0.27$. From most important to least important, the ranking is as follows: (a) average loan size as a percentage of per capita income (social), (b) default rate (financial), (c) cost to borrower (social), and (d) profitability (financial).

\section{Discussion}

We leverage a signaling lens to examine how the financial and social performance of MFIs shape the funding of crowdfunded microfinance campaigns. While prior studies have demonstrated the importance of entrepreneurs' characteristics in attracting funds for crowdfunding campaigns (e.g., Allison et al., 2013; Moss et al., 2018), the role of the MFI in attracting funding has been largely neglected. This dearth of research has remained despite calls for more investigation into the MFI's role in crowdfunded microfinance (e.g., Moss et al., 2015) and calls for further investigation into how crowdfunding platforms can be used to communicate positive signals to other prospective investors and stakeholders (Drover et al., 2017). Our work takes a step forward in answering these calls by providing evidence that an entrepreneur's MFI affiliation is a salient third-party signal in crowdfunded microfinance. Specifically, our results suggest that investors 


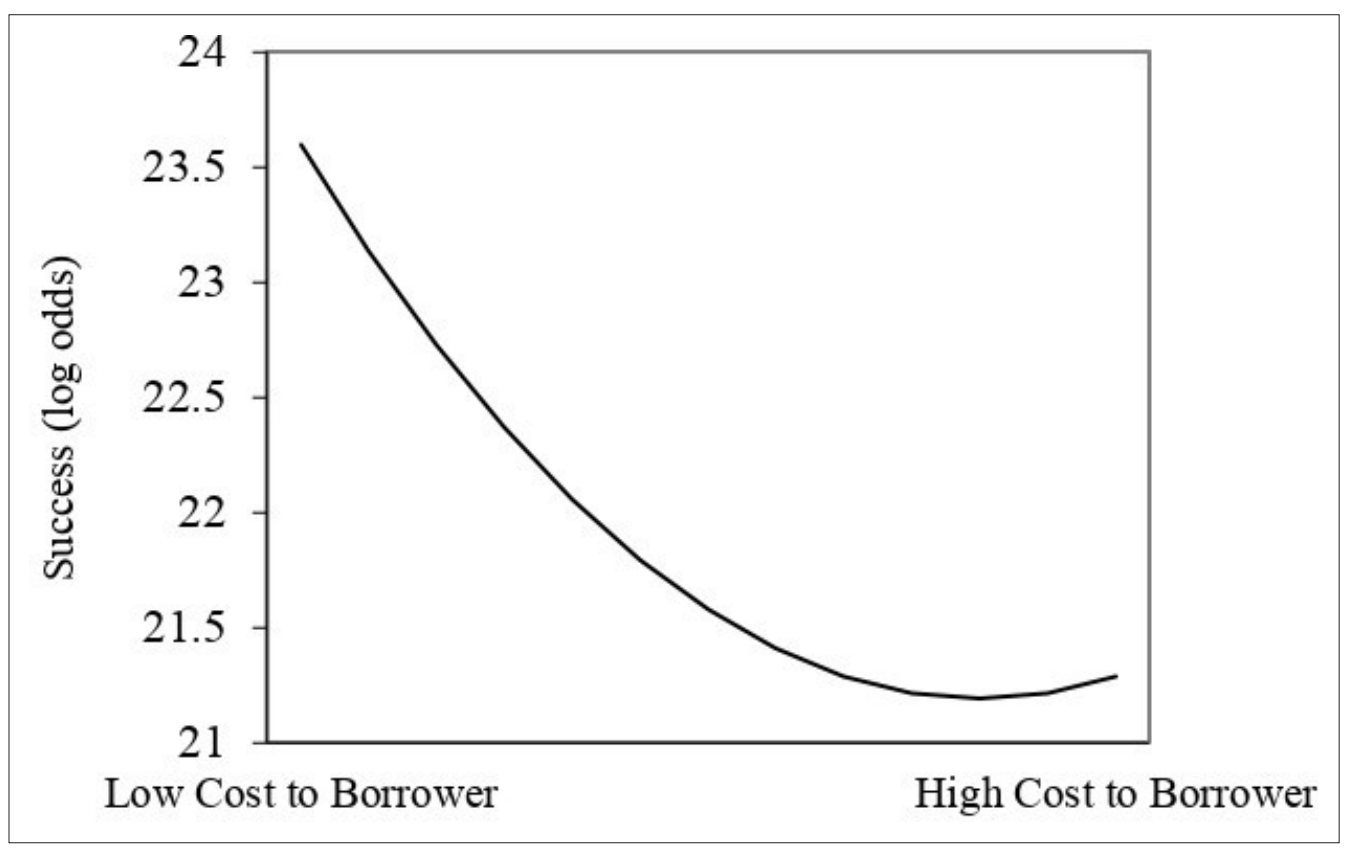

Figure 4. $[\mathrm{AQ} 11]$ Cost to borrower on success.

may consider the financial and social characteristics of MFIs in drawing inferences about the quality of individual crowdfunding campaigns. We provide insight into how investors balance the social and financial aspects of lending in crowdfunded microfinance. We show that both financial and social concerns are important with regard to MFIs, with an emphasis on helping being the largest factor driving funding. Our work has both theoretical implications for the understanding of third-party signals and practical implications for crowdfunded microfinance platforms.

\section{Theoretical Implications}

Third-party signaling research routinely examines how affiliation with another party shapes outcomes for the signaler. For example, a firm's affiliation with prestigious underwriters during an IPO sends a positive signal to investors because such underwriters are believed to have an ability to recognize quality (Bergh et al., 2014). This is often because the underwriters have a history of making profitable investments (Higgins \& Gulati, 2003). While it is common to view these third-party affiliations in binary (i.e., they exist or they do not; Plummer et al., 2016) or linear terms (e.g., more prestige is better; Chen, Hambrick, \& Pollock, 2008), research has shown that third-party signals often accrue nonlinear benefits to the signaler (e.g., Pollock, Chen, Jackson, \& Hambrick, 2010). Our work lends further support to this nonlinear view. We demonstrate that the financial and social characteristics of MFIs exhibit nonlinear relationships with the likelihood of funding. For instance, our results suggest that while investors value the social impact of their investment and seek to fund entrepreneurs associated with MFIs lending to the poorest individuals, this relationship diminishes as the average loan size becomes a larger percentage of per capita income, eventually becoming negative (at approximately $12.2 \%$ ). Accordingly, an affiliation with a socially-minded MFI cannot be viewed as a universally 
positive signal, but rather is dependent on the extent of the MFI's social performance. Likewise, while increasing default rates have a negative impact on funding, investors appear to be willing to continue lending up to a point (until defaults exceed 4.6\%). Thus, our results suggest a threshold up to which investors are willing to risk loss in order to fund impoverished entrepreneurs.

Our work also furthers understanding of how the socially oriented characteristics of the third party may benefit the signaler. Third-party signaling research has largely focused on the economically oriented characteristics of third parties, such as IPO track record or market position (e.g., Chang, 2004; Hoehn-Weiss \& Karim, 2014), paying much less attention to third parties' socially oriented characteristics. However, organizations that engage in socially oriented causes can enhance the reputation of the firm (Aguinis \& Glavas, 2012). For example, recent research in strategic management suggests that engaging in socially oriented causes may lead to positive investment evaluations (e.g., Ioannou \& Serafeim, 2015). It follows, then, that collaborating with organizations engaged in social activities may confer benefits as well, sending a positive signal to receivers. Our results support this idea: entrepreneurs can increase their likelihood of funding when associated with MFIs high in social performance (i.e., lower borrowing costs and higher loan size per capita).

Our study provides insight into investor motivations in crowdfunded microfinance. Using cognitive evaluation theory, past research indicates that while both cues are positively related to funding (Allison et al., 2015), intrinsic cues (i.e., framing the crowdfunding campaign as an opportunity to help others) dominate extrinsic cues (i.e., framing crowdfunding campaign as a business opportunity). When examining MFIs, our results appear consistent with this work. Our dominance analysis suggests that average loan size as a percentage of per capita income is the most dominant effect in our models (social), default rates (financial) and cost to borrowers (social) have similar effects, and profitability (financial) has little influence on funding. Accordingly, while investors balance social and financial concerns when examining their campaign contributions, social concerns appear to weigh more heavily in investment decisions. This adds credence to the idea put forward by Allison et al. (2015) that the emphasis on social concerns speaks to the "relative importance of intrinsic cues among a group of lenders who are intrinsically motivated and self-select into participating in crowdfunded microfinance" (p. 66).

Contrary to our second hypothesis, MFI profitability had no influence on the likelihood that a campaign was funded. Researchers have long noted that superior financial performance increases a third party's credibility (e.g., for VCs or investment banks; Chemmanur \& Fulghieri, 1994), thereby making associations with such parties a key signal (Drover et al., 2017). However, our finding might be explained by the unique aims of microfinance investors. Prior work has characterized these investors as seeking to balance social and economic concerns (Galak et al., 2011; Allison et al., 2015). Our results may hint at nuances regarding the latter. MFI default rates signal the creditworthiness of affiliated entrepreneurs and provide a direct indication of the likelihood that an individual investor will be repaid. Repayment personally affects investors' ability to recoup their contribution and to direct future contributions toward other loans. MFI profitability, on the other hand, has no direct implications for investors in that there is no immediate personal effect. Although entrepreneurs may endure a more rigorous screening process to partner with more profitable MFIs, because investors are not personally affected by MFI profitability, it is possible that investors assign little or no value to affiliations with an MFI higher in profitability. From a signaling perspective, for a signal to be a separating mechanism between lower and higher quality firms, receivers must assign value to the signal (Bergh et al., 2014). This concept is sometimes referred to as "signaling fit," wherein a particular signal must align with the expectations or concerns of receivers in order to be valuable (Connelly et al., 2011). Even though an affiliation with a more profitable MFI may be observable and costly in a signaling sense, perhaps 
it is not an important signal because it does not "fit" with the personal concerns of the investors.

\section{Practical Implications}

Our results hold practical implications for Kiva and other crowdfunded microfinance platforms. Specifically, because crowdfunding platforms need individuals to contribute to loans, our findings can be leveraged by such platforms in making and managing MFI partnerships. Crowdfunding organizations typically conduct due diligence to assess the financial stability and social impact of MFIs when forming a new partnership. This due diligence is performed in an effort to provide investors with a sense of security when making crowdfunding contributions and to provide evidence that their contributions are going to a good cause (e.g., Kiva, 2018c). Our results provide direct insight into how investors may react to the partnerships they make. For instance, our results suggest that the influence of default rates on the likelihood of funding levels out at values above $4.6 \%$ (22 are above this rate and 8 have default rates above 10\%). Because Kiva promotes a $97 \%$ repayment (3\% default) rate (Kiva, 2018a), expectations regarding payments are high and investors appear to only tolerate a small amount of defaults above this rate. As such, Kiva should be cautious about maintaining partnerships with MFIs with default rates in excess of $4.6 \%$.

Although a relatively small portion (13\%) of MFIs have default rates beyond the inflection point, this is not the case for the two social performance variables: 51 MFIs (30\%) have a cost to borrower greater than $35 \%$ and 58 MFIs (34\%) have an average loan size as a percentage of per capita income greater than $12.2 \%$. Our results suggest that this could be troublesome for Kiva in attracting funds to individual campaigns affiliated with these MFIs. However, it is worth noting the default rates average about $1 \%$ for these MFIs. As such, it is possible to that low default rates could offset the negative impact of these metrics when they are at levels beyond our calculated inflection points. While we hope our results provide crowdfunding platforms with insight into how investors may react to the financial and social performance of MFIs, we hasten to add that our analysis only examines each performance metric in isolation and weights each metric individually. We do not address the interplay among these performance metrics. Thus, future research might dive deeper into our findings and explore how performance configurations impact fundraising. Such research would provide insight into the tradeoffs that accompany financial and social performance of MFIs.

\section{Limitations and Future Research}

Our research examines how MFI affiliation can serve as a salient signal for entrepreneurs in crowdfunded microfinance. MFIs, however, may send signals in their own right that shape either crowdfunding performance or their partnership with Kiva, which we do not address. These signals may consist of traditional costly signals, such as partnerships, awards, or certifications. However, they may also include "costless" signals, which are defined as nonbinding and unverifiable messages (Bhattacharya \& Dittmar, 2003). Costless signals are intriguing in crowdfunding contexts because, while typically believed to be of little value, they have shown to be important in driving crowdfunding outcomes (e.g., Anglin et al., 2018). Kiva provides MFI descriptions and mission statements made by MFIs on its website. For instance, one MFI in our sample states

Such statements are "costless" in the sense that they are difficult to verify and are a matter of perspective. Nevertheless, an MFI describing itself as "innovative," "flexible," and "transparent" may shape both the willingness of investors to provide funds to crowdfunding campaigns and Kiva's willingness to partner with MFIs. Future researchers could leverage a series of qualitative 
interviews with Kiva to determine if/which costless signals resonate during the partnership process. These signals could then be evaluated for their influence on driving funds to individual crowdfunding campaigns.

Credo stands out in the Georgian microfinance sector because of its innovative, high quality products and its unique delivery mechanism focused on clients' wellbeing...It strives to offer flexible, convenient, transparent products and services to best meet the needs of its clients.

Our independent variable measures reflect important aspects of financial and social performance. However, a complete understanding of the implications of organizational performance requires accounting for the heterogeneity of environments, strategies, and management practices as well as the desires of multiple stakeholders (Richard, Devinney, Yip, \& Johnson, 2009). As such, it is unlikely that any one study could fully account for the complexity of how MFI performance shapeslending decisions. Thus, while we provide a foundation upon which to investigate how MFI performance shapes lending decisions, additional research is needed to fully understand the performance indicators that drive investment. For example, community initiatives (e.g., AIDS education or literacy programs) that go beyond making loans to the poor may serve as an indicator of social performance (e.g., van Rooyen, Stewart, \& de Wet, 2012). Because Kiva provides 'certifications' on the MFI's webpage for engaging in such activities, future research might explore how engaging these community initiatives impacts investment in crowdfunding campaigns.

\section{Conclusion}

Our work provides evidence that MFI affiliation operates as a key signal for entrepreneurs in crowdfunded microfinance. We find that an MFI's financial and social performance are predictive of the likelihood of an individual crowdfunding campaign being funded. For researchers, we take a needed step forward in understanding the role of the MFI as an important, but often overlooked, contextual factor affecting crowdfunded microfinance. For practitioners, we provide insight into how investors should be attentive to the characteristics of partnering MFIs, which we hope will inform crowdfunding platform-MFI partnership decisions.

\section{Declaration of Conflicting Interests[AQ12]}

The author(s) declared no potential conflicts of interest with respect to the research, authorship, and/or publication of this article.

\section{Funding}

The author(s) received no financial support for the research, authorship, and/or publication of this article.

\section{ORCID ID}

Aaron H. Anglin (iD) http://orcid.org/0000-0003-0857-2081

Thomas H. Allison (iD http://orcid.org/0000-0001-8873-9798

\section{References}

Aduda, J., \& Kalunda, E. (2012). Financial inclusion and financial sector stability with reference to Kenya: A review of literature. Journal of Applied Finance and Banking, 2(6), 95-120.

Aguinis, H., \& Glavas, A. (2012). What we know and don't know about corporate social responsibility: A review and research agenda. Journal of Management, 38(4), 932-968. 
Aguinis, H., \& Culpepper, S. A. (2015). An expanded decision-making procedure for examining cross-level interaction effects with multilevel modeling. Organizational Research Methods, 18(2), 155-176.

Ahlers, G. K. C., Cumming, D., Günther, C., \& Schweizer, D. (2015). Signaling in equity crowdfunding. Entrepreneurship Theory and Practice, 39(4), 955-980.

Ahlin, C., Lin, J., \& Maio, M. (2011). Where does microfinance flourish? microfinance institution performance in macroeconomic context. Journal of Development Economics, 95(2), 105-120.

Allison, T. H., McKenny, A. F., \& Short, J. C. (2013). The effect of entrepreneurial rhetoric on microlending investment: An examination of the warm-glow effect. Journal of Business Venturing, 28(6), 690-707.

Allison, T. H., Davis, B. C., Short, J. C., \& Webb, J. W. (2015). Crowdfunding in a prosocial microlending environment: Examining the role of intrinsic versus extrinsic cues. Entrepreneurship Theory and Practice, 39(1), 53-73.

Anglin, A. H., Allison, T. H., McKenny, A. F., \& Busenitz, L. W. (2014). The role of charismatic rhetoric in crowdfunding: An examination with computer-aided text analysis. In J. C. Short (Ed.), Social entrepreneurship and research methods (Vol. 919-48). Bingley, UK: Emerald Group Publishing.

Anglin, A. H., Short, J. C., Drover, W., Stevenson, R. M., McKenny, A. F., \& Allison, T. H. (2018). The power of positivity? The influence of positive psychological capital language on crowdfunding performance. Journal of Business Venturing, 33(4), 470-492.

Becchetti, L., \& Conzo, P. (2011). Enhancing capabilities through credit access: Creditworthiness as a signal of trustworthiness under asymmetric information. Journal of Public Economics, 95(3-4), 265-278.

Bergh, D. D., Connelly, B. L., Ketchen, D. J., \& Shannon, L. M. (2014). Signalling theory and equilibrium in strategic management research: An assessment and a research agenda. Journal of Management Studies, 51(8), 1334-1360.

Bhatt, N., \& Tang, S. -Y. (2001). Delivering microfinance in developing countries: Controversies and policy perspectives. Policy Studies Journal, 29(2), 319-333.

Bhattacharya, U., \& Dittmar, A. (2003). Costless versus costly signaling: Theory and evidence from share repurchases.

Bruton, G. D., Khavul, S., \& Chavez, H. (2011). Microlending in emerging economies: Building a new line of inquiry from the ground up. Journal of International Business Studies, 42(5), 718-739.

Budescu, D. V. (1993). Dominance analysis: A new approach to the problem of relative importance of predictors in multiple regression. Psychological Bulletin, 114(3), 542-551.

Canales, R., \& Greenberg, J. (2016). A matter of (relational) style: Loan officer consistency and exchange continuity in microfinance. Management Science, 62(4), 1202-1224.

Chan, C. S. R., \& Parhankangas, A. (2017). Crowdfunding innovative ideas: How incremental and radical innovativeness influence funding outcomes. Entrepreneurship Theory and Practice, 41(2), 237-263.

Chang, S. J. (2004). Venture capital financing, strategic alliances, and the initial public offerings of Internet startups. Journal of Business Venturing, 19(5), 721-741.

Chavas, J. -P., \& Holt, M. T. (1996). Economic behavior under uncertainty: A joint analysis of risk preferences and technology. The Review of Economics and Statistics, 78(2), 329-335.

Chemmanur, T. J., \& Fulghieri, P. (1994). Investment bank reputation, information production, and financial intermediation. The Journal of Finance, 49(1), 57-79.

Chen, G., Hambrick, D. C., \& Pollock, T. G. (2008). Puttin' on the Ritz: Pre-IPO enlistment of prestigious affiliates as deadline-induced remediation. Academy of Management Journal, 51(5), 954-975.

Colombo, M. G., Meoli, M., \& Vismara, S. (2019). Signaling in science-based IPOs: The combined effect of affiliation with prestigious universities, underwriters, and venture capitalists. Journal of Business Venturing, 34(1), 141-177.

Connelly, B. L., Certo, S. T., Ireland, R. D., \& Reutzel, C. R. (2011). Signaling theory: A review and assessment. Journal of Management, 37(1), 39-67.

Daher, L., \& Le Saout, E. (2013). Microfinance and financial performance. Strategic Change, 22(1-2), 31-45. 
Dineen, B. R., \& Allen, D. G. (2016). Third party employment branding: Human capital inflows and outflows following "Best Places to Work" certifications. Academy of Management Journal, 59(1), 90-112.

Drover, W., Busenitz, L., Matusik, S., Townsend, D., Anglin, A., \& Dushnitsky, G. (2017). A review and road map of entrepreneurial equity financing research: Venture capital, corporate venture capital, angel investment, crowdfunding, and accelerators. Journal of Management, 43(6), 1820-1853.

D’Espallier, B., Hudon, M., \& Szafarz, A. (2013). Unsubsidized microfinance institutions. Economics Letters, 120(2), 174-176.

Elitzur, R., \& Gavious, A. (2003). Contracting, signaling, and moral hazard: a model of entrepreneurs, 'angels,' and venture capitalists. Journal of Business Venturing, 18(6), 709-725.

Field, E., Pande, R., Papp, J., \& Rigol, N. (2013). Does the classic microfinance model discourage entrepreneurship among the poor? Experimental evidence from India. American Economic Review, 103(6), 2196-2226.

Galak, J., Small, D., \& Stephen, A. T. (2011). Microfinance decision making: A field study of prosocial lending. Journal of Marketing Research, 48(SPL), S130-S137.

Gulati, R., \& Higgins, M. C. (2003). Which ties matter when? The contingent effects of interorganizational partnerships on IPO success. Strategic Management Journal, 24(2), 127-144.

Higgins, M. C., \& Gulati, R. (2003). Getting off to a good start: The effects of upper echelon affiliations on underwriter prestige. Organization Science, 14(3), 244-263.

Hoehn-Weiss, M. N., \& Karim, S. (2014). Unpacking functional alliance portfolios: How signals of viability affect young firms' outcomes. Strategic Management Journal, 35(9), 1364-1385.

Hoetker, G. (2007). The use of logit and probit models in strategic management research: Critical issues. Strategic Management Journal, 28(4), 331-343.

Ioannou, I., \& Serafeim, G. (2015). The impact of corporate social responsibility on investment recommendations: Analysts' perceptions and shifting institutional logics. Strategic Management Journal, 36(7), 1053-1081.

Jeong, S. -H., \& Harrison, D. A. (2017). Glass breaking, strategy making, and value creating: Meta-analytic outcomes of women as CEOs and TMT members. Academy of Management Journal, 60(4), 1219-1252.

Johnson, J. W., \& Lebreton, J. M. (2004). History and use of relative importance indices in organizational research. Organizational Research Methods, 7(3), 238-257.

Josefy, M., Dean, T. J., Albert, L. S., \& Fitza, M. A. (2017). The role of community in crowdfunding success: Evidence on cultural attributes in funding campaigns to "save the local theater". Entrepreneurship Theory and Practice, 41(2), 161-182.

Kiva. (2018a). About us. Retrieved from https://www.kiva.org/about

Kiva. (2018b). Where Kiva works. Retrieved from https://www.kiva.org/about/where-kiva-works/partner

Kiva. (2018c). Due diligence and monitoring. Retrieved from https://www.kiva.org/about/due-diligence

Kyereboah-Coleman, A., \& Osei, K. A. (2008). Outreach and profitability of microfinance institutions: The role of governance. Journal of Economic Studies, 35(3), 236-248.

Marakkath, N., \& Attuel-Mendès, L. (2015). Can microfinance crowdfunding reduce financial exclusion? regulatory issues. International Journal of Bank Marketing, 33(5), 624-636.

Marotta, D. J., \& Russell, M. (2016). Micro loans: Give a little, help a lot. USA Today, January, 16. Retrieved from https:/www.usatoday.com/story/money/personalfinance/2016/01/16/advice-iq-microloans $/ 78877246 /$

Mersland, R., \& Urgeghe, L. (2013). International debt financing and performance of microfinance institutions. Strategic Change, 22(1-2), 17-29.

Moss, T. W., Neubaum, D. O., \& Meyskens, M. (2015). The effect of virtuous and entrepreneurial orientations on microfinance lending and repayment: A signaling theory perspective. Entrepreneurship Theory and Practice, 39(1), 27-52. 
Moss, T. W., Renko, M., Block, E., \& Meyskens, M. (2018). Funding the story of hybrid ventures: Crowdfunder lending preferences and linguistic hybridity. Journal of Business Venturing, 33(5), 643-659.

Ozmel, U., Reuer, J. J., \& Gulati, R. (2013). Signals across multiple networks: How venture capital and alliance networks affect interorganizational collaboration. Academy of Management Journal, 56(3), $852-866$.

Paravisini, D., Rappoport, V., \& Ravina, E. (2017). Risk aversion and wealth: Evidence from person-to-person lending portfolios. Management Science, 63(2), 279-297.

Pollock, T. G., Chen, G., Jackson, E. M., \& Hambrick, D. C. (2010). How much prestige is enough? Assessing the value of multiple types of high-status affiliates for young firms. Journal of Business Venturing, 25(1), 6-23.

Randøy, T., Strøm, R. Øystein., \& Mersland, R. (2015). The impact of Entrepreneur-CEOs in microfinance institutions: A global survey. Entrepreneurship Theory and Practice, 39(4), 927-953.

Reuer, J. J., Tong, T. W., \& Wu, C. -W. (2012). A signaling theory of acquisition premiums: Evidence from IPO targets. Academy of Management Journal, 55(3), 667-683.

Richard, P. J., Devinney, T. M., Yip, G. S., \& Johnson, G. (2009). Measuring organizational performance: Towards methodological best practice. Journal of Management, 35(3), 718-804.

Roberts, P. W. (2013). The profit orientation of microfinance institutions and effective interest rates. World Development, 41, 120-131.

Roberts, P. W., \& Dowling, G. R. (2002). Corporate reputation and sustained superior financial performance. Strategic Management Journal, 23(12), 1077-1093.

Reuer, J. J., Tong, T. W., \& Wu, C. -W. (2012). A signaling theory of acquisition premiums: Evidence from ipo targets. Academy of Management journal, 55(3), 667-683.

Sadeh, F., \& Kacker, M. (2018). Quality signaling through ex-ante voluntary information disclosure in entrepreneurial networks: Evidence from franchising. Small Business Economics, 50(4), 729-748.

Sauerwald, S., Lin, Z. J., \& Peng, M. W. (2016). Board social capital and excess CEO returns. Strategic Management Journal, 37(3), 498-520.

Short, J. C., Ketchen, D. J., McKenny, A. F., Allison, T. H., \& Ireland, R. D. (2017). Research on crowdfunding: Reviewing the (very recent) past and celebrating the present. Entrepreneurship Theory and Practice, 41(2), 149-160.

Spence, A. M. (1974). Market signaling: Informational transfer in hiring and related screening processes. Cambridge, MA: Harvard University Press.

Sun, S. L., \& Im, J. (2015). Cutting microfinance interest rates: An opportunity co-creation perspective. Entrepreneurship Theory and Practice, 39(1), 101-128.

Thorpe, D (2018). Kiva is really a crowdfunded bank for refugees and other 'unbankables'. Forbes, September, 24. Retrieved from https://www.forbes.com/sites/devinthorpe/2018/09/24/kiva-is-really-a-crowdfunded-bank-for-refugees-and-other-unbankables/\#533b491a220a

van Rooyen, C., Stewart, R., \& de Wet, T. (2012). The impact of microfinance in sub-Saharan Africa: A systematic review of the evidence. World Development, 40(11), 2249-2262.

\section{Author Biographies}

\section{Aaron H. Anglin II}

Jeremy C. Short II

David J. Ketchen II

Thomas H. Allison II

Aaron F. McKenny II 